\author{
Снежана В. БОЖИЋ \\ Филозофски факултет \\ Универзитет у Нишу
}

Оригинални научни рад

Примљен: 26. 12. 2019.

Прихваћен: 12. 02. 2020.

\title{
ЧИТАЛАЦ И/ИЛИ АУТОР - ОДИСЕЈАДА КРОЗ МРЕЖУ РЕФЕРЕНЦИ
}

\begin{abstract}
На трагу теорије књижевног хипертекста Џорџа Лендоуа (George Landow) и ергодичке књижевности Еспена Арсета (Espen Aarseth), у раду се бавимо делима Драгана Бошковића и Саше Илића Одисеј: каталошка прича (1998) и Срђана В. Тешина Антологија најболих наслова (2000), настојећи да утврдимо разлоге због којих се ова остварења могу одредити као изразити али атипични примери лексикографско-енциклопедијског модела у српској књижевности. Већ и начином на који су их њихови поетички освешћени аутори дефинисали (експеримент; роман у фрагментима), они проблематизују сопствену егзистенцију у оквиру одређеног жанра (нпр. романа), док формом и садржином испитују могуће видове али и границе комуникације с читаоцем, који се у чину рецепције нужно налази у улози коју Лендоу именује читалаи-као-писаи (reader-as-author). Управо је позиција читаоца она која нас примарно интересује. То је полазиште за испитивање досегнутог домета поменутих књижевних експеримената: њихове улоге у тренутку објављивања, веза (линкова) успостављених са претходним и потоњим сродним остварењима, као и, шире гледано, позиције и значаја који (у Текстленду/Textland српске књижевности) имају данас.

Кључне речи: теорија хипертекста, ергодичка књижевност, постмодернистичка проза, књижевни експеримент, читалац, каталошка прича, фрагмент.
\end{abstract}

\section{... Читалаи јесте текст и сваки његов контакт са светом представља читање света. \\ (Одисеј: каталошка прича, 65)}

Координате књижевнотеоријског и књижевноисторијског оквира у који овим радом покушавамо да сместимо коауторски текст Одисеј: каталошка прича Драгана Бошковића и Саше Илића и Антологију најбољих наслова Срђана Тешина у време настанка и објављивања ових дела (1998. и 2000) биле су углавном већ исцртане; данас, након двадесетак година, оне се чине јасно утврђеним и неупитним, али и даље сазнајно изазовним. И као што

\footnotetext{
*snezana.bozic@filfak.ni.ac.rs
} 
картографи најпре у своје мапе уносе најистакнутије објекте из окружења, да би се на основу њих лакше оријентисали у простору/времену, а после се баве доцртавањем и допуњавањем финеса, уношењем појава које крајолику дају коначну физиономију, тако и ми видимо задатак који смо овде себи поставили. (Притом, ни картографија није тек случајна асоцијација, без додатне значењске носивости.) Рекло би се, наиме, да су кључне, најистакнутије тачке „територије” српске књижевности последње деценије двадесетог и прве деценије 21. века добро проучене и описане; наше је да, имајући то у виду, сагледамо и неке њене помало скрајнуте, сеновите кутке, занимљива места која су својевремено и перципирана као таква, остајући маркирана, али без много детаљнијих осврта.

Трасирајући пут кроз нове пределе виртуелне кюижевности, Владислава Гордић Петковић осврће се на Текстленд/Textland који, у Oдисејy, установљују Бошковић и Илић, одређујући га као „мрежу нарација”, „свет апсолутне уметности у коме књижевно дело није импровизован 'нужни смештај' Приче, већ помно конструисана мрежа путева која води до великих нарација”, свет у настајању (2004: 9, 15). У поглављу под насловом „Путовање у Текстленд" она повезује два, односно три аутора којима се овде бавимо и њихова остварења, указујући и на друге, тада млађе ствараоце који су прионули на изградњу таквог света. Хипертекстуални експеримент Oдисеј и виртуелнолитерарни пројекат Антологија најбољих наслова - појављују се, у њеној визури, као истурена одељења „Дирекције за обнову и изградњу литературе” [...] „најмлађе српске прозе” (Гордић Петковић 2004: 15).

Другу, општију маркацију узимамо од Тихомира Брајовића. Издвајајући у оквиру постмодернистичког концепта три главне струје, павићевску, албахаријевску и басаријанску, он Срђана Тешина смешта у групу „поетички разуђене генерације постмодернистички опредељених писаца у најширем значењу речи, различитих сензибилитета", при чему је (уз Милоша Латиновића) виђен као нови-стари настављач борхесовско-павићевских мистификација (Брајовић 2009: 92), док име Саше Илића у Брајовићевом бедекеру проналазимо међу „пливачима мимо главних струја”, као једну у низу „занимљивих појава на маргини”, сагледану, примарно, кроз роман Берлинско окно (2005), „изразито критички интониран, антиратни и политички актуелан, односно морално провокативан и хуманистички апелативан” (Брајовић 2009: 100).

Тако је књижевни експеримент Одисеј, можда због, временски гледано, нешто ранијег појављивања, радикалнијег поетичког искорака или пак коауторства, остао скрајнут, па је у Илићевој и у Бошковићевој биобиблиографији за многе (истраживаче) „само успутна биографска белешка" (Ћирић, 2014). Овај мултимедијални пројекат, пропраћен и изложбом у Студентском културном центру, својевремено је остао без већег одјека јавности. С обзиром на чињеницу да је Одисеј: каталошка прича књига којом су, према речима Александра Јеркова, „Саша Илић и Драган Бошковић програмски одредили крајњи домет нове текстуалности и затражили другачије путеве књижевних епифанија" (Јерков 2001, подвукла С. Б.) а да 
стоји на почетку њихових стваралачких каријера, ${ }^{1}$ док је, у ширем контексту српске књижевности, она део књижевних струјања на размеђи два века, чини се да није ирелевантно вратити јој се. Притом смо за повратак и Одисеју и Антологији изабрали пут који настоји да повеже ове књижевне текстове са хипертекстом, ${ }^{2}$ због чега и сам тај пут задобија нека епифанијска обележја. Оправдање за то налазимо у чињеници да је хипертекст у последњој деценији прошлог века и касније представљао једно од истакнутих обележја великих промена, технолошких и културолошких, које су се десиле на глобалном нивоу и имале одређене импликације у књижевној теорији и пракси.

На различите везе хипертекста, као нове технологије писања, читања и комуникације (која има дужу историју настанка и развоја) $)^{3}$ и постмодерне прозе већ је указивано, а теорија хипертекста довођена је у везу с постструктуралистичком теоријском мишљу. У том смислу, значајно је име Џорџа Лендоуа (George Landow) једног од првих и најутицајнијих теоретичара хипертекста, који већ начином дефинисања овог кључног појма успоставља конвергенцију с постструктуралистичким радовима о интертексту и текстуалности уопште, омогућивши тиме да се „у информационе технологије и дигиталне текстуалне манифестације уведу концепти и механизми текстуалне анализе" (Успенски 2012: 84).

Појава књижевног хипертекста, ${ }^{4}$ који је за кратко време привукао велику пажњу и нашао се у средишту интересовања једног круга теоретичара књижевности, медија и културе, променила је начин на који почињу да се посматрају и „класична”, штампана књижевна дела, савремена и она старија. То је било могуће захваљујући, с једне стране, особинама самог хипертекстуалног медија и, с друге, карактеристичним теоријским преокретом у посматрању књижевног дела и његове рецепције. Професионални читаоци познаваоци хипертекста одређена књижевна остварења технологије штампе сада препознају као претече хипертекстуалног писања, или их виде као хипертекстуалне облике. Реч је о постојећим експерименталним књижевним текстовима предтехнолошког раздобља, различитим покушајима нелинеар-

\footnotetext{
${ }^{1}$ Књига Одисеј: каталошка прича објављена је 1998. године у едицији „Прва књига” Матице српске.

${ }^{2}$ Хипертекст - „информациона технологија која се састоји од појединачних блокова текста, или лексија и електронских линкова који их повезују” (Лендоу 1994: 1); „,асемблаж нехијерархизованих докумената који су повезани линковима” (Гордић Петковић 2004: 8), „електронски текст, написан за читање на рачунару, који се реализује у виртуелном простору компјутерских комуникација и обележен је нелинеарношћу и варијантношћу, а чија се природа одређује одсуством ограничења линеарног простора, као и интерактивним могућностима, и за који је карактеристичан плурализам дискурса и одустајање од фиксације текста” (Татаренко 2013: 145).

${ }^{3}$ Видети о томе: (Божић 2018: 71-121).

${ }^{4}$ Књижевни хипертекст дефинише се као „текст доступан читаоцу на екрану монитора рачунара (то јест на више екранских страница), представљен у нелинеарном облику, са назначеним везама путем којих се читалац, по свом избору, може кретати унутар понуђене мреже страница / сегмената текста - а који нема превасходно документарно-информативну функцију (већ га аутор ствара и читалац потом препознаје као вид књижевности према неким одликама писања и написаног)" (Ерор 2001: 9).

${ }^{5}$ Књижевни критичари, теоретичари и историчари књижевности.
} 
ног писања, тј. разарања линеарне структуре текста, који представљају антиципацију оних могућности које ће донети нови медији; ${ }^{6}$ овим се потврђују ставови да историја нелинеарне писмености започиње у предтехнолошком раздобљу, као и да предисторија хипертекста започиње пре појаве првих рачунара (Божић 2018: 81). Заједничко им је промењено, другачије искуство у процесима читања и писања у односу на, условно речено, традиционално, линеарно, односно измене у релацијама аутор - дело - читалац. Јављају се и нова терминолошка одређења таквих текстова, као што су нова хипертекстуалност, дефинисана као „прозни експеримент који се заснива на конструкцији паралелних светова, на раслојавању приче, сучељавању заплета и јунака, позајмљених из већ написаних књига, са оригиналним ауторовим" (Гордић Петковић 2004: 8) или протохипертекстови - дела технологије штампе која својом формом антиципирају могућности будућег електронског текста (новомедијског текста / дигитекста, Успенски 2012: 83), а појавила су се пре 1987. године када је објављено дело које се сматра првим (правим) књижевним хипертекстом (По подне, прича Мајкла Џојса), као и друга одређења. Најзначајнијим ипак сматрамо увођење појма ергодичности и ергодичке књижевности, за шта заслуге припадају норвешком теоретичару Еспену Арсету (Espen Aarseth) а који се објашњава преко концепта сајбертекста. Тај концепт усредсређен је на механичку организацију текста која сложеност (мрежност) самог медија поставља као интегрални део литерарне размене, у којој је корисник текста (тј. читалац) фигура у много већој мери интегрисана у сам процес. Сајбертекст се реализује као низ одлука и избора које читалац доноси у процесу читања, с тим што се његова активност не одвија само у глави (на менталном нивоу), већ подразумева и одређену физичку активност конструкције и селекције (на пример, избор одређеног линка у хипертексту физичким „кликом” на дугме миша). Управо ту појаву Арсет означава појмом ергодичности (изведеним од грч. речи ергон и ходос, рад и пуm). Дакле, ергодичка књижевност била би она која од читаоца захтева одређени рад који му омогућава кретање кроз текст, активност другачију од уобичајене (каква је нпр. покрет очију и периодично окретање страница). У фокусу Арсетовог интересовања су дела дигиталне, тј. „нове” ергодичке књижевности (књижевни хипертекстови, различите врсте компјутерских видео-игара и сл.), али он из својих разматрања не искључује ни текстове који припадају ранијим технологијама писања (,стару” ергодичку књижевност). У том смислу, појам ергодичности представља корисно проширење постојеће теоријске апаратуpe, јер омогућава истовремено проучавање књижевности на новим медијима и књижевних дела преддигиталног периода која захтевају сличну (физичку) активност читаоца у слеђењу, односно откривању текстуалних путева у чину рецепције (нпр. при читању Павићевог Хазарског речника). ${ }^{7}$

Описани контекст показује се као значајан, јер се оба текста о којима је у овом раду реч, Одисеј: каталошка прича и Антологија најбољих наслова,

\footnotetext{
${ }^{6}$ Израз нови медији подразумева „компјутерске технологије, телекомуникације и могућности које пружа интернет" (Nadrljanski i Nadrljanski 2008: 45).

${ }^{7}$ Више о овоме видети: Успенски 2012; Божић 2018: 81-91.
} 
због базичне стваралачке идеје из које су настали, целокупне поставке, реализације, па и одјека - могу сматрати парадигматичним примерима књижевних дела која припадају преддигиталној, „старој” ергодичкој књижевности, протохипертекстовима у правом значењу те речи. Поред тога, она су и репрезентативна дела српске постмодернистичке књижевности, у којима се лако препознају многе карактеристике текућих књижевно-теоријских струјања: „нове комбинације уметности и стварности, популарног и елитног, патетичног и ироничног, својеврсни еклектицизам", заснованост на интертекстуалности, цитатности (Константиновић 1992: 629), затим проблематизација одређених идеја модернизма какве су систем, јединство, целовитост, центрираност, као и општеобавезујућих критеријума - истинитости, објективности, универзалности... (Бужињска, Марковски 2009: 369).

Текстови Тешина, Бошковића и Илића на прилично експлицитан начин илуструју теоријске концепте о којима је претходно било речи. То је дозвољавало да у време објављивања буду виђени и као антиципација будућих дела домаће електронске књижевности или као простор практичне реализације концепата описаних у радовима раних теоретичара хипертекста, какав је Џорџ Лендоу. Ово нарочито долази до изражаја у делу Одисеј: каталошка прича. Иако то чини на начин потпуно аутохтон (уз завидно и неопходно књижевнотеоријско утемељење које је /било/ у поседу њених аутора), ова каталошка прича сасвим је актуелна, у „дослуху” са свим релевантним кретањима у европској и светској књижевности и науци о књижевности у тренутку свог објављивања.

Позиција и улога читаоца представља питање свих питања у Oдисеjy, о чему сведочи и други део књиге, текст под називом „Нова митологија (један поетички експеримент)” који један од аутора, Драган Бошковић, у својој библиографији наводи као научни рад. Осамнаест ,певања” Одисеја, заправо 18 каталошких пописа (са по десет референци, изузев десетог певања које, у првом делу, има једанаест сигнатура, и последњег, осамнаестог са две дуплиране аутореференце), од „Огигије” до „Абадоновог штита” (називи поглавља), излажу, како објашњава Бошковић у теоријској експликацији ${ }^{8}$ коауторског експеримента, „предложак за једну причу која је у латентном стању и [...] њена реализација зависи од индивидуе која ће јој посветити своје време и биће. Тог тренутка каталошка прича добија свог јунака који долази из реалног света и упушта се у читалачку авантуру, а његов пут представља археологију приче задате каталошком матрицом" (Одисеј, 61). Референце су у поглавља уврштене углавном према тематском принципу, са повременим празнинама (празним каталошким листићима) остављеним читаоцу да их у коауторском стваралачком чину допуни својим избором. Крећући се, ментално, од референце до референце, читалац постаје главни јунак, Одисеј. На делу је интеракција у којој се одређене референце „инхерентно интертекстуал-

${ }^{8}$ Сасвим у духу онога како то, на Западу, раде Марк Америка (Маrк Amerika), Роберт Кувер (Robert Coover) и други писци и теоретичари хипертекстуалне књижевности. Врло често су њихови хипертекстуални радови праћени теоријским објашњењима. Видети о томе: (Божић 2018: 100-102). 
ном стратегијом процесом менталног линковања" евоцирају у ум читаоца са којим су у интеракцији (Успенски 2012: 84). Присуство емпиријског читаоца као главног јунака „уноси ред и успоставља нову метастазу значења у простор између два каталошки фиксирана текста"; текстуализујући, нехотице, своју стварност, јунак-читалац омогућава да каталошка прича постигне своју стабилност. Истовремено, присуство аутора је у чину стварања света прuче/прича сведено на минимум, јер стваралачки чин преузима читалац. Тако „рецепција постаје једнака акцији стварања” (Одисеј, 71). У трансформацији категорије читаоца (на релацији читалац-стваралац-лик) иде се још даље, до ситуације у којој „нови читалац доживљава сопствену стварност као текст, а то се остварује пројектовањем свих прочитаних садржаја у исту стварност (текстуализација). Свака секвенца живота, догађај или доживљај, преображавајући се на нивоу текстуалне свести читаоца, постају део животног текста" (Исто). Овим су постојећа схватања улоге читаоца-као-аутора донекле коригована, јер ,за разлику од читаоца који егзистира у сферама доживљаја исписаних текстова, стварајући интерпретативном авантуром неочекивана значења, читалац каталошке приче понире кроз скривена значења текстова у стварност, где и он и текст налазе ослонац.” Димензије саме стварности обликују се према димензијама могућих светова књижевних дела. „Свет књижевности даје печат свету око нас, ликови из дела одређују ликове људи с којима долазимо свакодневно у контакт” (Oдисеј, 73). Новом „творцу-читаоцу [...] отвара се могућност да живи себе и свој живот као ТЕКСТ” (Исто).

Издвојили смо само нека у мноштву места која у овом „поетичком експерименту" позивају на детаљније разматрање категорија аутора, читања и читаоца, присуства и одсуства текста, односа мита, митског коментара и доживљене стварности, нове епифаније, феномена „подизања приче”, затим питања жанра, односа текстуалне и емпиријске стварности, и друга. Имплицитно позивање читаоца на дијалог о наведеним питањима потврђује генерално схватање да је постмодернистички текст у суштини намењен интелектуалној читалачкој публици.

Роман у фрагментима Срђана Тешина лако се доводи у везу са Арсетовим концептом ергодичности. Занимљиво је да као један од парадигматичних примера „старе” ергодичке књижевности Арсет наводи и Кортасарове Школице, које видимо као структурно блиске Тешиновој Антологији. Оне „представљају зачетак енциклопедијске парадигме у савременом роману, с нагласком на нелинеарном читању, умножавању ауторских фигура и цитатности" (све собине које утичу на формална обележја текста, његову спољашњу структуру и организацију). У критичкој литератури је већ било осврта на везу Школииа и Павићевог Хазарског речника. Закључку да ,романескна форма Школица проистиче из интегралистичке визије света аргентинског писца, која ће двадесет година касније навести Милорада Павића да у потпуности реализује поетичку револуцију коју је Кортасар тек наслутио” (Вранеш 2019: 46) додајемо да је Срђан Тешин ту Павићеву револуцију потврдио, пишући, у сличном поетичком кључу, свој роман у фрагментима. Ова књига састоји се од 49 фрагмената/реченица (алузија на Пинчонову Објаву броја 
49) која „читаоцу отвара могућност хипертекстуалног креативног писања” (Гордић Петковић 2004: 16), јер свака од тих реченица може бити заплет једног могућег романа. Испод сваког фрагмента читаоцу се нуди инструкција да прочитано упореди са неким другим фрагментима у књизи. На тај начин могуће је склопити одређен број повести различитих ликова, чији се попис налази у индексу на крају романа. Слеђење датих упутстава читаоца уводи у ,лавиринт са мноштвом раскршћа и путева који се рачвају и уливају у нове или, под другачијим углом, у старе”, а роман се претвара у „књигу без правог почетка, краја и разрешења, у серију варијација и концентричних кругова са различитим значењима, те њиховим постепеним надоградњама и променама” (Бакић 2001). Није тешко замислити Тешинов роман као прави књижевни хипертекст. У критици је тако и виђен: „на средокраћи између Хераклита и хипертекста" (Гордић Петковић).

Још један занимљив аспект истраживања отвара се компаративним приступом Одисеју и Антологији. Бошковићева и Илићева каталошка прича својеврсни је контрапункт Антологији, а Антологија на неки начин комплементарна Одисеју. Њихово довођење у поредбену везу додатно истиче својеврсну текстуалну испражњеност, прусуство у одсуству (минус присуство), укидање наратива с једне и могућност да се прича ипак ишчита, с друге стране. Док код Тешина приче/фрагменти опстају (умножавају се и укрштају) као „остатак смисла у једном разломљеном, распршеном дискурсу изолованих наслова” (Владушић 2007: 152), Одисеј доноси „експлицитно одсуство текста - странице су прекривене само добро организованим сигнатурама које упућују на имплицитно присутне текстове. Хиперинтертекстуални однос изгледа овако: експлицитни текст извесног књижевног дела - одсутни текст каталошке приче!” (Одисеј, 65-66).

Истраживачко лутање реалним и вирутелним просторима конструисаних светова прича успостављених у чину рецепције Тешиновог и БошковићевогИлићевог књижевног остварења уместо закључака отвара низ питања. Каквог то читаоца тражи Oдисеј, с каквим читалачким навикама и склоностима? Колико је „обичан” читалац спреман на дуго ходање у Одисејевим сандалама не би ли успоставио какву-такву онтолошку стабилност каталошке приче? У крајњој линији, ко је „циљна група” књижевног експеримента и који је његов смисао? Има ли, уопште, смисла? Није ли Одисеј последица и/или производ који потврђује да „за каталогизацијом посеже ерудиција која покушава да буде инвентивна" (Гордић Петковић 2004: 24)?

Питања се множе. Како би се „одисејада” трансформисала и одвијала ако бисмо је пренели у виртуелне просторе интернета, односно све дате сигнатуре претворили у хиперлинкове? И како би се наше искуство читања променило кад бисмо фрагменте Тешиновог романа линковали на начин сугерисан у тексту? Шта је заједничко, а шта суштински различито између каталошке приче, овакве каква је дата, и неког могућег књижевног хипертекста насталог на основу штампаног предлошка?

Теорије о којима је било речи у овом раду настојале су да дају одговоре на оваква питања. Зауставићемо се у навођењу бројних истраживачких под- 
стицаја издвајањем места које, можда, нуди још неки одговор. То је у Oдисејy описан феномен „подизања приче”, могућност да се допре до њене друге, „оне” стране: „Прича се подиже и испод ње остаје само сигнатура која лебди над понором стварности, који је могуће осветлити бљеском књижевног садржаја истиснутог из сигнатуре (епифанија) и момента стварности. Бљесак се представља као неочекивани смисао дарован читаоиу. Подизањем приче одстрањује се њен 'изглед', њена самозаконитост и отвара се поглед у 'апсолут'. Ето начина да се директно сусретнемо лицем у лице са бићем књижевности" (Одисеј, 87-88).

Шта ће се, дакле, десити ако „подигнемо” каталошку причу? Има ли разлике ако/када је она електронска? Какву епифанију нам то доноси, а шта причи/причама одузима? Можда бљеска/неочекиваног смисла неће ни бити, можда ће остати само продужен истраживачки поглед на траг приче, на њихове трагове.

Евоцирајући овим питањима неке изворне идеје попут мемекса (В. Буша) или докуверзума (Т. Нелсона), ${ }^{9}$ можда можемо замислити бескрајан (умрежени) виртуелни простор у коме обитавају сви у једном тренутку створени и сви будући светови прича свих читалаца, прошлих, садашњих и будућих, оних текстова на које Одисеј реферира, и других, који се ту не помињу. Тако „вишак значења” које Oдисеј нуди егзистира истовремено у различитим димензијама, у споју рецепције књижевности као социјално обликованог чина (сетимо се, на пример, интерпретативних заједница Стенлија Фиша или схватања књижевности као друштвене праксе Стеина Олсена) и читања које представља интимно, дубоко лично искуство. Тежња да се те димензије, уједињене у духу, на неки начин оваплоте (материјализују, кондензују) на одређеним координатама реалног живота/емпирије и остваре „нову зону максималног контакта са стварношћу” резултира установљавањем Текстленда, чије су координате исцртане на правој географско-књижевној мапи Града (Београда или било ког другог града на свету), приложеној у књизи. Њено разгледање и тумачење позива читаоца на још једну игру - дешифровања кључних места мапе и креирања сопствене. Дакле, интерактивност која је у првом делу Бошковићеве и Илићеве књиге подразумевала „попуњавање” датих референци садржајима похрањеног сопственог читалачког искуства сада добија нову димензију. Мапирањем/креирањем сопственог Текстленда читалац-као-аутор, „творац-читалац”, постаје и учесник књижевног експеримента, картограф који део сопствене личне историје/памћења (читања и живљења) уноси у књижевност.

„Сфере текста и света налазе се у отвореном односу једна према другој. Текстом се проширује хоризонт егзистенције, чиме јој се увећава значење за сва значења која проистичу из књижевног дела. Стварност се поново изграђује и смисаоно проширује. Књижевност ствара свет и преправља га" (Одисеј, 86).

\footnotetext{
${ }^{9}$ Видети о томе: (Божић 2018: 73-76).
} 


\section{ЛИТЕРАТУРА}

Aрсет 1997: E. Aarseth, Cybertext: Perspectives on Ergodic Literature. Baltimore: The Johns Hopkins University Press.

Бакић 2001: И. Бакић, Борхесов рај (Антологија најбољих наслова-роман у фрагментима, Срђан В. Тешин, Београд: Рад 2000), доступно на: http:// ilijada.blogspot.com/2012/07/borhesov-raj-antologija-najboljih.html [24. 12. 2019].

Божић 2018: С. Божић, Пријатељство на Мрежи: о интернету и настави књижевности, Ниш: Филозфски факултет.

Брајовић 2009: Т. Брајовић, Кратка историја преобиља, Зрењанин: Агора.

Бужињска, Марковски 2009: A. Bužinjska, M. P. Markovski, Književne teorije XX veka, Beograd: Službeni glasnik.

Владушић 2007: С. Владушић, На промаји, Зрењанин: Агора.

Вранеш 2019: К. Вранеш, Енциклопедијска парадигма у Школиияама Хулија Кортасара и Хазарском речнику Милорада Павића, 49. Међународни научни састанак слависта у Вукове дане, Лексикографско-енциклопедијска парадигма у српској прози: тезе и резимеи, 12-16. 9. 2019, Београд: Филолошки факулет,

Гордић Петковић 2004: V. Gordić Petković,Virtuelna književnost. Beograd: Zavod za udžbenike i nastavna sredstava.

Epop 2001: G. Eror, O pojmu književnog hiperteksta, Београд: Къижевна историја, вол. 33, бр. 113-115, 5-38.

Јерков 2001: A. Jerkov, Budnost i spasenje, Vreme, br. 537, 19. 4. 2001, dostupno na: https://www.vreme.com/cms/view.php?id=114065 [24. 12. 2019].

Константиновић 1992: Z. Konstantinović, Postmodernizam, u: Rečnik književnih termina (prir. D. Živković), Beograd: Nolit.

Лендоу 2006: G. Landow, Hypertext 3.0: critical theory and new media in an era of globalization. Baltimore: The Johns Hopkins University Press.

Лендоу 1994: G. Landow, Hypertext Theory, Baltimore: The Johns Hopkins University Press.

Надрљански и Надрљански 2008: Đ. Nadrljanski i M. Nadrljanski, Digitalni mediji-obrazovni softver, Sombor: Pedagoški fakultet.

Татаренко 2013: А. Татаренко, Поетика форме у прози српског постмодернизма, Београд: Службени гласник.

Успенски 2012: I. Uspenski, Hipertekst kao tekstualnost interneta i modeli sajbercentričnog čitanja, Art+Media: časopis za studije umetnosti i medija, br. 1, septembar 2012, 83-92.

Ćirić 2014: S. Ćirić, Traži se praher za ljubavni tepih - kratka povest „radikalnih eksperimenata" u prozi, Beton, br. 150, 20. 8. 2014, dostupno na https://www. elektrobeton.net/cement/trazi-se-praher-za-ljubavni-tepih/ [24. 12. 2019]. 


\section{Snežana V. Božić}

\section{READER AND/OR AUTHOR - NOSTOS THROUGH A NETWORK OF REFERENCES}

\section{(Summary)}

Following the theory of literary hypertext by George Landow and ergodic literature by Espen Aarseth, in this paper we are discussing the works Odysseus: Catalogue Story (1998) by Dragan Bošković and Saša Ilić and Anthology of Best Titles (2000) by Srđan B. Tešin, trying to determine all reasons why these works might be perceived as pronounced but atypical examples of the lexicographic-encyclopedic model in Serbian literature. The exact definitions chosen by their poetically conscious authors (experiment; novel in fragments) present the issues of their actual existence within the stated genre (for example, novel), while the form and content of each work are exploring the possible forms and boundaries of communication with the reader, which is, within the act of reception, necessarily assigned the role of reader-as-author, as named by Landow. We are primarily interested in this position of the reader. It is the starting point for examining the achieved range of mentioned literary experiments: their roles at the time of publishing, connections (links) with the previous and later related works, and in the wider scheme of things likewise the positions and significance in the present day (within the Textland of Serbian literature). 